\title{
Relationship between Levels of Student Alienation and Hemsehrilik Attitudes of University Students: A Study on Kyrgyz-Turkish Manas University Students
}

\author{
Yücel Öksüz ${ }^{1}$, Melek Baba Öztürk ${ }^{2, *}$ \\ ${ }^{1}$ Department of Psychology, Faculty of Literature, Kyrgyz-Turkish Manas University, Kyrgyzstan \\ ${ }^{2}$ Department of Primary Education, Faculty of Education, Ondokuz Mayis University, Turkey
}

Copyright $\mathrm{O} 2017$ by authors, all rights reserved. Authors agree that this article remains permanently open access under the terms of the Creative Commons Attribution License 4.0 International License

\begin{abstract}
This research is aimed to reveal the relationships between students' alienation levels and their "hemsehrilik" attitudes. However, it is examined whether students' alienation levels and "hemsehrilik" attitudes differentiated with regards to various variables as gender, class, the number of sibling and parents' home city in this research. The research was prepared at relational screening model. It was attended to 300 university students who studied at Kyrgyz Turkish Manas University in 2015-2016 academic year in spring term. Data were collected through "Student Alienation Scale" developed by Çağlar [1] and "University Students of Hemsehrilik Attitude Scale" developed by Öksüz [2] The analysis of data were used to mean, standard deviation, frequency and percentage as well as independent samples of t test, one-way ANOVA and correlation analysis. It was found that university students' alienation levels were affected by class and parents' home city. Also, students' hemsehrilik attitudes were affected by gender, parents' home city and the number of sibling. However, it was not found a significant relation between students" alienation level and "hemsehrilik" attitude.
\end{abstract}

Keywords Alienation, Student Alienation, Hemsehrilik, University Students, Kyrgyz- Turkish Manas University

\section{Introduction}

It is a known fact that cultural, social and technological transformations and developments give rise to a number of problems as well as making contributions to the lives of individuals. Alienation is one of these problems manifesting itself in different forms and characteristics such as burnout, loneliness and isolation, and severely affecting the social, societal and professional lives of individuals. Alienation refers, in the most general sense, to isolation and withdrawal from an environment, people, a social group or society with which one interacts. Although alienation has been known and used as a concept since the beginning of humanity, it seems to have been defined in different ways by researchers [3]. For example, approaching the concept from an individual perspective, Horney [4] considers alienation to be a negative process involving abandonment of emotions, thoughts, desires and energy. On the other hand, Finifter [5] regards alienation as a sociologically-based process which results in one's withdrawal from the group, society, values or organization in which one is. Interpreting the concept from a similar point of view, Mann defines alienation as "the state or experience of being isolated from a group or an activity to which one should belong or in which one should be involved." [1] Tolan [6] also refers to alienation as "man's becoming distant to himself, to the product he produces, to his natural and social environment but under the control of their dominance." All these definitions point to the presence of two basic approaches that constitute the theoretical framework of alienation. One of them is the Marxist sociological approach which treats alienation as a social and historical process while the other is the psychological approach based on existentialism which considers alienation an indispensable part of human life [1] Although the definitions of alienation are different from one another, they are basically constructed, methodized and improved based on these two approaches.

Although alienation, with its density, prevalence and various forms, is regarded as peculiar to modern society, it would not be wrong to claim that it is a long-standing phenomenon which has made its presence felt especially in production organizations and in many other fields such as education, health and art. At this point, it can be stated that alienation experienced in the field of education is relatively new. According to Sidorkin [7], alienation in education involves individuals' withdrawal from learning and teaching processes, their growing disinterest in these processes and 
education being reduced to a boring, monotonous and unappealing activity. There are many factors playing a role in the emergence of this situation depending on the source of alienation. According to Şimşek and Katitaş [8] these factors can be addressed in two groups as in-school and out-of-school factors or categorized and examined as organizational and environmental factors. Independently of previous classifications, this study made a new classification by taking into account the group which has been affected by alienation. According to the new classification, the factors causing alienation can be addressed in two groups as "factors that affect the educator and the learner." Table 1 shows what these factors are (with the relevant research results):

Table 1. Factors Causing Alienation in Education

\begin{tabular}{|c|c|c|}
\hline $\begin{array}{c}\text { Affected } \\
\text { Group }\end{array}$ & Factors & $\begin{array}{l}\text { Relevant } \\
\text { Studies }\end{array}$ \\
\hline Teachers & $\begin{array}{l}\text { Teachers' personality traits, expectations, } \\
\text { desires and beliefs; their socio-economic } \\
\text { status such as age, sex, place of birth, place } \\
\text { of residence, marital status and number of } \\
\text { children; course load, class size; their } \\
\text { working hours and branches; attitudes of } \\
\text { school administrators; lack of belonging; } \\
\text { bureaucratic structure of schools }\end{array}$ & $\begin{array}{c}{[9,10,11,} \\
12,13]\end{array}$ \\
\hline Students & $\begin{array}{l}\text { Intensive curriculum with no connection to } \\
\text { real life; lack of self-control; indifference } \\
\text { and negative attitudes of families; age, sex, } \\
\text { social circle; negative communication with } \\
\text { teachers and school administrators; } \\
\text { movement-limiting conditions; economic } \\
\text { status; work out of school; lack of sense of } \\
\text { belonging to school; problems related to } \\
\text { academic interest and success }\end{array}$ & $\begin{array}{c}{[3,1,14,13,} \\
15]\end{array}$ \\
\hline
\end{tabular}

The factors stated in Table 1 may negatively affect teachers and students, causing them to lose interest in and motivation to the education process, to live a sense of burnout and loneliness and, by extension, to create a sense of alienation from their environment, their work or from the education activity itself.

Known for his studies on this issue, Hoşgörür [16] states that alienation reduces the creativity of teachers, discourages them to improve their professional skills, lowers their effectiveness and productivity in learning-teaching processes, curtails their cooperation with colleagues, and undermines their contribution to students' individual and social development processes. Also constituting the focus of this study, the effect of alienation on students is explained with a four-dimensional structure by Mau [17]. According to Yilmaz and Sarpkaya [18], each of these dimensions; powerlessness, normlessness, meaninglessness and isolation actually points to an end in itself. The first dimension, powerlessness, refers to having high-level objectives despite low expectation of achieving these objectives. According to Akar and Aydin [19], powerlessness constitutes an important dimension of alienation. The situation of students who want to get high grades but have low academic achievement is given as an example of powerlessness by sources [17].
Constituting the second dimension of alienation, normlessness manifests itself in the way that students object to decisions which school administration or teachers make about them. They abide by the rules when authority is present while they break the rules when authority is absent.

The third dimension of alienation is meaninglessness. According to Mau [17] students who experience meaninglessness believe that some courses have no connection with everyday life and so they oppose the teaching of those courses.

The last dimension, isolation, estrangement or social isolation, refers to the situation where one is segregated from one's community or reduces one's contact with members of that community to minimum and withdraws oneself from social ties. Mau [17] emphasizes that students who experience social isolation regard the school and classroom environment as disordered, crowded and complicated. There are numerous studies in the literature that address student alienation in various ways $[20,21,22,23,24,14,25,26,27$, $28,29,30,31,32,33,34,35,36,15]$. Some of these studies provide a descriptive assessment by examining alienation in terms of socio-demographic characteristics, while others focus on the association of alienation with such variables as loneliness, organizational cynicism, academic achievement and attitudes toward the teaching profession [37]. There are, however, no studies which have examined the relationship between "hemsehrilik" and student alienation. Therefore, the aim of this study is to reveal the relationship between the levels of alienation of university students and their "hemsehrilik" attitudes.

As is known, university is an important social organization bringing together people of different sexes, languages, religions, ethnicities and cultures. Through the environment it creates and resources it provides, university offers the opportunity to experience a new academic, personal and social life for those people who differ greatly from each other [38]. This situation is known to bring with it some problems along with its positive aspects [39]. Involving in university life, young people move away from the environment and people they are familiar with and enter a new circle, and have to interact with other young people who have different views, life styles and understandings from them. The student profile of Kyrgyzstan Turkey Manas University shows that there are a large number of students from different countries outside of Kyrgyzstan, especially from Turkey. The majority of Kyrgyz students come from other provinces outside Bishkek [40]. This can lead to such problems as stress, anxiety, loneliness and adjustment problems in young people. However, every young person goes to university with certain expectations and wishes on their mind. When these expectations are not met, they may feel discontent and maladjusted, and therefore, alienated from the environment and people. It may be necessary to analyze and strengthen the sources of social support in order for individuals to do away with alienation and to achieve academic, personal and social fulfillment. In this respect, "hemsehrilik" ties are considered to be a strong 
form of solidarity which provides young people with the support they need and reduces alienation.

\subsection{Objective of the Study}

This study aimed to determine the relationship between the level of alienation of students of Kyrgyzstan Turkey Manas University and their "hemsehrilik" attitudes. This study also investigated whether the students' alienation levels and "hemsehrilik" attitudes showed any statistically significant difference in terms of some of the variables listed below. Accordingly, the sub-problems examined within the scope of this study are as follows:

1. What is the level of alienation of students participating in the study?

2. Do the levels of alienation of the students participating in the study show any statistically significant difference depending on sex, grade level, place of residence of family and number of siblings?

3. What is the level of "hemsehrilik" attitudes of students participating in the study?

4. Do the levels of "hemsehrilik" attitudes of students participating in the study show any statistically significant difference depending on sex, grade level, place of residence of family, family type and number of siblings?

5. Is there a statistically significant relationship between the levels of alienation and "hemsehrilik" attitudes of students participating in the study?

\section{Method}

\subsection{Research Model}

Aiming to reveal the relationship between the levels of alienation and "hemsehrilik" attitudes of university students, this study is an example of the relational screening model which is defined in the literature as "a research model which tries to determine the existence and direction of the relationship between two or more variables" [41]Therefore, the relational screening model is the model of choice in this study as it aimed to determine the relationship between "hemsehrilik" attitudes and alienation levels of students.

\subsection{Study Group}

The study group is composed of 300 students studying at different faculties and departments of Kyrgyzstan Manas University (KTMU) in the spring semester of 2015-2016 academic year. The selection of students was based on voluntary participation and those who stated that they wanted to participate in the study were included in the study group. Table 2 presents the demographic information of these students.
Table 2. Study Group

\begin{tabular}{|c|c|c|c|}
\hline Variables & Group & $\mathrm{f}$ & $\%$ \\
\hline \multirow{3}{*}{ Gender } & Female & 240 & 80,0 \\
\cline { 2 - 4 } & Male & 60 & 20,0 \\
\hline \multirow{3}{*}{ Grade Level } & 1 & 86 & 28,7 \\
\cline { 2 - 4 } & 3 & 84 & 28,0 \\
\cline { 2 - 4 } & 4 & 74 & 24,7 \\
\hline \multirow{3}{*}{$\begin{array}{c}\text { Number of Siblings } \\
\text { Place of Residence } \\
\text { of Family }\end{array}$} & Two or fewer & 126 & 18,7 \\
\cline { 2 - 4 } & Three or more & 174 & 42,0 \\
\cline { 2 - 4 } & Live in provinces & 130 & 43,0 \\
\cline { 2 - 4 } & Live in districts & 71 & 23,7 \\
\hline \multirow{3}{*}{$\begin{array}{c}\text { Live in villages } \\
\text { Family Type }\end{array}$} & $\begin{array}{c}\text { The broken } \\
\text { families }\end{array}$ & 79 & 33,0 \\
\cline { 2 - 4 } & $\begin{array}{c}\text { The nuclear } \\
\text { families }\end{array}$ & 192 & 23,3 \\
\cline { 2 - 4 } & $\begin{array}{c}\text { The extended } \\
\text { families }\end{array}$ & 38 & 12,7 \\
\hline
\end{tabular}

Table 2 shows that $80 \%$ of the students are female and $20 \%$ are male. $28.7 \%$ of the students are first-graders, $28 \%$ second-graders, $24.7 \%$ third-graders and $18.7 \%$ fourth-graders. $42 \%$ of the students have two or fewer, and $58 \%$ have three or more siblings. $43.3 \%$ of the families of the students live in provinces, $23.7 \%$ live in districts and $33 \%$ live in villages. $23.3 \%$ of the students live with broken families, $64 \%$ live with nuclear families and $12.7 \%$ live with extended families. Since the university has a Turkish-medium education system, all the participants can speak, read and write well in Turkish.

\subsection{Data Collection Tools}

In this study, "Student Alienation Scale" and "Hemsehrilik Attitude Scale of University Students" (HASUS) were used as data collection tools. Detailed information on these data collection tools is given below.

\subsubsection{Student Alienation Scale}

The Student Alienation Scale was developed by Çağlar (2012) to measure the level of alienation of students. The scale consists of 4 sub-dimensions and 20 items. These sub-dimensions are powerlessness, normlessness, meaninglessness and isolation. 11 of 20 items contain statements on presence of alienation and the remaining 9 items contain statements on lack of alienation. The items were rated using a five-point Likert type scale, ranging from "I strongly disagree" to "I strongly agree". The scores on the scale provide an overall assessment of the level of alienation. Accordingly, the lowest and highest scores that can be obtained from the scale are 20 and 100 , respectively, indicating the higher the score(s), the more intense alienation. Table 3 shows the levels of alienation developed by Çağlar based on the total scale scores. 
Table 3. Levels of Student Alienation

\begin{tabular}{|c|c|c|c|}
\hline \multirow{4}{*}{} & \multicolumn{2}{|c|}{ Score Interval } & Levels \\
\cline { 2 - 4 } & Total Score & Item & \\
\cline { 2 - 4 } $\begin{array}{c}\text { Student } \\
\text { Alienation }\end{array}$ & $20-35$ & $1.00-1.79$ & Very Low \\
\cline { 2 - 4 } & $36-51$ & $1.80-2.59$ & Low \\
\cline { 2 - 4 } & $52-67$ & $2.60-3.40$ & Medium \\
\cline { 2 - 4 } & $68-83$ & $3.41-4.21$ & High \\
\cline { 2 - 4 } & $84-100$ & $4.22-5.00$ & Very High \\
\hline
\end{tabular}

Table 3 demonstrates that the level of alienation of individuals who score between 0 and 20 is very low, between 36 and 51 low, between 52 and 67 medium, between 68 and 83 high and above 84 very high. The validity and reliability analyses of the scale were carried out by Çağlar in 2012 and the following results were obtained. The internal consistency of the subscales was .86 and the internal consistency coefficients of the subscales varied between .75 and .79 . The internal consistency coefficient of the scale calculated within the scope of this study is .73, suggesting that the scale can be used as a reliable data collection tool in this study and similar studies. The validity analyses indicate that the structure obtained from the exploratory factor analysis was supported by the confirmatory factor analysis. The values obtained from the confirmatory factor analysis are as follows: $\mathrm{X}^{2}=326.96, \mathrm{sd}=164, \mathrm{X}^{2} / \mathrm{sd}=1.99, \mathrm{NNFI}=.95, \mathrm{CFI}=.95$, $\mathrm{RMSEA}=.05, \mathrm{SRMR}=.05, \mathrm{GFI}=.91, \mathrm{AGFI}=.89$ and $\mathrm{CFI}=.95$.

\subsubsection{Hemsehrilik Attitude Scale of University Students} (HA 'SUS)

HASUS was developed by Öksüz (2012) to determine hemsehrilik attitudes of university students. The scale consists of 21 items, rated on a five-point Likert-type scale. The exploratory factor analysis carried out on the scale within the scope of validity tests indicates that the scale consists of 21 positive items and one dimension. The obtained structure was also supported by the confirmatory factor analysis. The values obtained from the confirmatory factor analysis are as follows: $\mathrm{X}^{2} / \mathrm{sd}=2,65, \mathrm{RMSEA}=0.07$, $\mathrm{CFI}=0.96, \mathrm{GFI}=0.86, \mathrm{AGFI}=0.83$ and $\mathrm{NFI}=0.93$. The internal consistency coefficient calculated within the reliability of the scale is .91 . The lowest score is 21 and the highest score is 105 , indicating the higher the score(s), the higher the hemsehrilik attitude.

\subsection{Data Collection and Analysis}

The data were collected during the spring semester of the 2015-2016 academic year. Prior to data collection, students were briefly informed on the purpose of the study. Students who agreed to participate in the study were given forms that included the data collection tools, and the average response time of each form lasted about 10 minutes. The data obtained in a total of three weeks with a duration of about 20-25 minutes were analyzed using SPSS 17.00. Before the analysis, skewness coefficients, box graphs and Kolmogorov-Smirnov/Shapiro-Wilk values were examined to determine whether the data showed a normal distribution or not. The table below shows K-S/S-W values:

Table 4. Kolmogorov-Smirnov/Shapiro-Wilk Values

\begin{tabular}{|c|c|c|c|c|c|c|}
\hline \multirow{2}{*}{ Variables } & \multirow{2}{*}{ Group } & \multirow{2}{*}{$\mathrm{N}$} & \multicolumn{2}{|c|}{$\overline{\mathrm{X}}$} & \multicolumn{2}{|c|}{ K-S/S-W } \\
\hline & & & HA & SA & HA & SA \\
\hline \multirow{2}{*}{ Gender } & Female & 240 & 2,72 & 2,53 & ,101 & ,094 \\
\hline & Male & 60 & 2,90 & 2,58 & ,083 & ,078 \\
\hline \multirow{4}{*}{ Grade Level } & 1 & 86 & 2,81 & 2,43 &, 053 &, 166 \\
\hline & 2 & 84 & 2,76 & 2,52 & ,465 & ,193 \\
\hline & 3 & 74 & 2,69 & 2,69 & ,139 & ,411 \\
\hline & 4 & 56 & 2,78 & 2,54 &, 165 &, 111 \\
\hline \multirow{2}{*}{ Number of Siblings } & Fewer than three & 126 & 2,85 & 2,59 & ,247 & ,464 \\
\hline & Three or more & 174 & 2,69 & 2,50 &, 123 &, 101 \\
\hline \multirow{3}{*}{$\begin{array}{c}\text { Place of Residence of } \\
\text { Family }\end{array}$} & Live in provinces & 130 & 2,83 & 2,60 & 210 & ,176 \\
\hline & Live in districts & 71 & 2,62 & 2,41 &, 159 &, 051 \\
\hline & Live in villages & 99 & 2,76 & 2,54 & ,079 & ,288 \\
\hline
\end{tabular}


The scores obtained from both scales were converted to z-score during the analysis and interpretations were made considering the following intervals:

1.00-1.79= Very Low/I strongly disagree

$1.80-2.59=$ Low $/$ I disagree

2.60-3.40=Medium/Undecided

3.41-4.21 $=$ High $/$ agree

4.22-5.00=Very High/I strongly agree

\section{Results}

Results in this section were presented according to the sub-problems of the study.

\subsection{Results Related to the Sub-Problem "What is the Level of Alienation of Students Participating in the Study?"}

Table 5 shows the results regarding the level of alienation of the students.

Table 5. Level of Alienation of Students

\begin{tabular}{|c|c|c|c|c|}
\hline & $\mathrm{N}$ & $\overline{\mathrm{X}}$ & $\mathrm{Sd}$ & Min-Max.Values \\
\hline $\begin{array}{c}\text { Student } \\
\text { Alienation }\end{array}$ & 300 & 2.54 & 0.50 & $1.40-3.75$ \\
\hline
\end{tabular}

As can be seen in Table 5, the arithmetic mean of the scores of the students on the alienation scale is $\bar{X}=2.54$ and the standard deviation is $\mathrm{s}=0.50$, indicating that the level of alienation of the students is low.

\subsection{Results Related to the Sub-Problem "Do the Levels of Alienation of the Students Participating in the Study Show Any Statistically Significant Difference Depending on Sex, Grade Level, Place of Residence of Family, Number of Siblings?"}

\subsubsection{Results Related to Sex}

An unrelated samples t-test was used to compare the alienation levels of the students by sex and the results were presented in Table 6.

Table 6. Comparison of Levels of Alienation of Students by Sex

\begin{tabular}{|c|c|c|c|c|c|c|}
\hline & $\mathrm{N}$ & $\overline{\mathrm{X}}$ & $\mathrm{Sd}$ & $\mathrm{sd}$ & $\mathrm{t}$ & $\mathrm{p}$ \\
\hline Female & 240 & 2.53 & 0.49 & \multirow{2}{*}{298} & \multirow{2}{*}{-0.665} & \multirow{2}{*}{.507} \\
\cline { 1 - 4 } Male & 60 & 2.58 & 0.54 & & & \\
\hline
\end{tabular}

Table 6 shows that there is not a statistically significant difference in the levels of alienation of the students between the two sexes $\left(\mathrm{t}_{298}=-0.665, \mathrm{p}>.05\right)$. The arithmetic means of the female and male students' scores are $\bar{X}=2.53$ and $\bar{X}=2.58$, respectively. The difference between the means indicate that the level of alienation of the male students is higher than that of the female students; however, the difference is not statistically significant.

\subsubsection{Results Related to Grade Level}

A one-way ANOVA test was performed to determine whether the levels of alienation of the students varied depending on their grade levels. For this, first, a Levene homogeneity test (Levene $=0.490, \mathrm{p}>.05$ ) was conducted. The result of the test indicated that the variances were homogeneous and so a one-way ANOVA test was applied. Table 7 presents the results of the one-way ANOVA test.

Table 7. Comparison of Levels of Alienation of Students by Grade Level

\begin{tabular}{|c|c|c|c|c|c|c|c|}
\hline & $\mathrm{N}$ & $\overline{\mathrm{X}}$ & $\mathrm{Sd}$ & $\mathrm{df}$ & $\mathrm{F}$ & $\mathrm{p}$ & $\begin{array}{c}\text { Significant } \\
\text { Difference }\end{array}$ \\
\hline 1 & 86 & 2.43 & 0.46 & & & & \\
\cline { 1 - 3 } 2 & 84 & 2.52 & 0.51 & \multirow{2}{*}{$3-296$} & \multirow{2}{*}{3.709} & .012 & $1-3^{*}$ \\
\hline 3 & 74 & 2.69 & 0.51 & & & & \\
\cline { 1 - 4 } 4 & 56 & 2.54 & 0.50 & & & & \\
\hline
\end{tabular}

Table 7 shows that there is a statistically significant difference in the levels of alienation of the students between grade levels $\left(\mathrm{F}_{(3-296)}=3.709, \mathrm{p}<.05\right)$. Analyses performed to determine which groups caused this difference indicate that the mean score $(\bar{X}=2.69)$ of the third grade students is higher than that of the first grade students $(\overline{\mathrm{X}}=2.43)$.

\subsubsection{Results Related to Place of Residence of Family}

A one-way ANOVA test was carried out to determine whether the levels of alienation of the students varied depending on place of residence of their families. For this, first, a Levene homogeneity test (Levene $=0.695, \mathrm{p}>.05$ ) was conducted. As the variances were homogeneous, a one-way ANOVA test was performed. Table 8 demonstrates the results of the one-way ANOVA test.

Table 8. Comparison of Levels of Alienation of Students by Place of Residence of Family

\begin{tabular}{|c|c|c|c|c|c|c|c|}
\hline & $\mathrm{N}$ & $\bar{X}$ & $\mathrm{Sd}$ & df & $\mathrm{F}$ & $\mathrm{p}$ & $\begin{array}{c}\text { Significant } \\
\text { Difference } \\
\text { (Tukey) }\end{array}$ \\
\hline Province & 130 & 2.60 & 0.51 & \multirow{3}{*}{$2-297$} & \multirow{3}{*}{3.620} & \multirow{3}{*}{.028} & \multirow{3}{*}{$\begin{array}{c}\text { Province- } \\
\text { District }\end{array}$} \\
\hline District & 71 & 2.41 & 0.47 & & & & \\
\hline Village & 99 & 2.54 & 0.51 & & & & \\
\hline
\end{tabular}

Table 8 indicates that there is a statistically significant difference between the levels of alienation of the students in terms of the place of residence of their families $\left(\mathrm{F}_{2-297}=3.620\right.$, $\mathrm{p}<.05)$. Analyses conducted to determine which groups caused this difference show that the levels of alienation $(\bar{X}=2.60)$ of the students whose families live in provinces are higher than those $(\bar{X}=2.41)$ of the students whose families live in districts.

\subsubsection{Results Related to Number of Siblings}

An unrelated samples t-test was carried out to determine whether the levels of alienation of the students differ according to the number of siblings, and the obtained results were given in Table 9. 
Table 9. Comparison of Levels of Alienation of Students by Number of Siblings

\begin{tabular}{|c|c|c|c|c|c|c|}
\hline & $\mathrm{N}$ & $\overline{\mathrm{X}}$ & $\mathrm{Sd}$ & $\mathrm{sd}$ & $\mathrm{t}$ & $\mathrm{P}$ \\
\hline Fewer than 3 & 126 & 2.59 & 0.49 & \multirow{2}{*}{298} & \multirow{2}{*}{1.531} & \multirow{2}{*}{.127} \\
\hline 3 or more & 174 & 2.50 & 0.51 & & & \\
\hline
\end{tabular}

As can be seen in Table 9, there is not a statistically significant difference between the levels of alienation of the students in terms of the number of siblings $\left(t_{298}=1.531\right.$, $\mathrm{p}>.05)$. Although the mean score $(\bar{X}=2.59)$ of the students with fewer than 3 siblings is higher than that $(\overline{\mathrm{X}}=2.50)$ of the students with 3 or more siblings, the difference is not statistically significant.

\subsection{Results Related to the Sub-Problem "What is the Level of Hemsehrilik Attitudes of Students Participating in the Study?"}

Table 10 shows the results of hemsehrilik attitudes of the students.

Table 10. Hemsehrilik Attitudes of Students

\begin{tabular}{|c|c|c|c|c|}
\hline & $\mathrm{N}$ & $\overline{\mathrm{X}}$ & $\mathrm{Sd}$ & Min-Max.Values \\
\hline Hemsehrilik & 300 & 2.76 & 0.45 & $1.62-3.86$ \\
\hline
\end{tabular}

As can be seen from Table 10, the arithmetic mean and standard deviation of the scores of the students on the hemsehrilik attitude scale are $\bar{X}=2.76$ and $\mathrm{Sd}=0.45$, respectively, indicating that the hemsehrilik attitudes of the students are moderate.

\subsection{Results Related to the Sub-Problem Do the Levels of Hemsehrilik Attitudes of Students Participating in the Study Show Any Statistically Significant Difference Depending on Sex, Grade Level, Place of Residence of Family, Family Type and Number of Siblings?}

\subsubsection{Results Related to Sex}

An unrelated samples t-test was used to compare the students' hemsehrilik attitudes by sex, and the results were presented in Table 11.

Table 11. Comparison of Students' Hemsehrilik Attitudes by Sex

\begin{tabular}{|c|c|c|c|c|c|c|}
\hline & $\mathrm{N}$ & $\overline{\mathrm{X}}$ & $\mathrm{Sd}$ & $\mathrm{Sd}$ & $\mathrm{t}$ & $\mathrm{P}$ \\
\hline Female & 240 & 2.72 & 0.44 & \multirow{2}{*}{298} & -2.811 & .005 \\
\cline { 1 - 5 } Male & 60 & 2.90 & 0.47 & & & \\
\hline
\end{tabular}

As can be seen from Table 11, hemsehrilik attitudes of the students significantly differ depending on sex $\left(\mathrm{t}_{298}=-2.811\right.$, $\mathrm{p}<.05$ ), indicating that hemsehrilik attitudes of the male students are higher than those of the female students.

\subsubsection{Results Related to Grade Level}

A one-way ANOVA test was conducted to determine whether the students' hemsehrilik attitudes differed by grade level. For this purpose, first, a Levene homogeneity test
(Levene $=0.249, \mathrm{p}>.05)$ was carried out. As the variances were homogeneous, a one-way ANOVA test was conducted. Table 12 presents the results of the one-way ANOVA test.

Table 12. Comparison of Students' Hemsehrilik Attitudes by Grade Level

\begin{tabular}{|c|c|c|c|c|c|c|c|}
\hline & $\mathrm{N}$ & $\overline{\mathrm{X}}$ & $\mathrm{Sd}$ & $\mathrm{Sd}$ & $\mathrm{F}$ & $\mathrm{P}$ & $\begin{array}{c}\text { Significant } \\
\text { Difference }\end{array}$ \\
\hline 1 & 86 & 2.81 & 0.39 & & & & \\
\cline { 1 - 3 } 2 & 84 & 2.76 & 0.45 & \multirow{2}{*}{$3-296$} & \multirow{2}{*}{0.878} & .453 & - \\
\hline 3 & 74 & 2.69 & 0.47 & & & & \\
\hline 4 & 56 & 2.78 & 0.51 & & & & \\
\hline
\end{tabular}

Table 12 shows that there is not a statistically significant difference in hemsehrilik attitudes of the students between grade levels $\left(\mathrm{F}_{(3-296)}=0.878, \mathrm{p}>.05\right)$. Although the arithmetic mean of the scores of the first grade students $\left(\overline{\mathrm{X}}_{1}=2.81\right)$ is higher than those of the second, third and fourth grade students $\left(\overline{\mathrm{X}}_{2,3,4}=2.76,2.69\right.$ and 2.78), the difference is not statistically significant.

\subsubsection{Results Related to Place of Residence of Family}

A one-way ANOVA test was performed to determine whether the students' hemsehrilik attitudes differed by place of residence of their families. To this end, first, a Levene homogeneity test (Levene $=0.066, \mathrm{p}>.05$ ) was conducted. Since the variances were homogeneous, a one-way ANOVA test was carried out. Table 13 demonstrates the results of the one-way ANOVA test.

Table 13. Comparison of Students' HemsehrilikAttitudes by Place of Residence of Family

\begin{tabular}{|c|c|c|c|c|c|c|c|}
\hline & $\mathrm{N}$ & $\overline{\mathrm{X}}$ & $\mathrm{Sd}$ & $\mathrm{Sd}$ & $\mathrm{F}$ & $\mathrm{P}$ & $\begin{array}{c}\text { Significant } \\
\text { Difference }\end{array}$ \\
\hline Province & 130 & 2.83 & 0.49 & & & & \\
District & 71 & 2.62 & 0.40 & $2-297$ & 5.120 & .007 & $\begin{array}{c}\text { Province- } \\
\text { District }\end{array}$ \\
\cline { 1 - 6 } Village & 99 & 2.76 & 0.41 & & & & \\
\hline
\end{tabular}

Table 13 shows that there is a statistically significant difference between hemsehrilik attitudes of the students in terms of place of residence of their families $\left(\mathrm{F}_{2-297}=5.120\right.$, $\mathrm{p}<.05$ ). Analyses carried out to determine which groups caused this difference indicate that hemsehrilik attitudes of the students whose families live in provinces $(\bar{X}=2.83)$ are higher than those of the students whose families live in districts $(\overline{\mathrm{X}}=2.62)$.

\subsubsection{Results Related to Number of Siblings}

An unrelated samples t-test was performed to determine whether the students' hemsehrilik attitudes differ depending on the number of siblings and the results were given in Table 14.

Table 14. Comparison of Students' Hemsehrilik Attitudes by Number of Siblings

\begin{tabular}{|c|c|c|c|c|c|c|}
\hline & $\mathrm{N}$ & $\overline{\mathrm{X}}$ & $\mathrm{Sd}$ & $\mathrm{sd}$ & $\mathrm{t}$ & $\mathrm{P}$ \\
\hline Fewer than 3 & 126 & 2.85 & 0.45 & \multirow{2}{*}{298} & \multirow{2}{*}{3.087} & \multirow{2}{*}{.002} \\
\hline 3 or more & 174 & 2.69 & 0.44 & & & \\
\hline
\end{tabular}


Table 14 shows that there is a statistically significant difference between the students' hemsehrilik attitudes in terms of the number of siblings $\left(\mathrm{t}_{298}=3.087, \mathrm{p}<.05\right)$. The mean score $(\overline{\mathrm{X}}=2.85)$ of the students with fewer than 3 siblings is higher than that $(\overline{\mathrm{X}}=2.69)$ of the students with 3 or more siblings.

\subsection{Results Related to the Sub-Problem "Is There a}

Statistically Significant Relationship between the Levels of Alienation and Hemsehrilik Attitudes of Students Participating in the Study?"

The Pearson correlation coefficient was used to determine the relationship between the students' hemsehrilik attitudes and levels of alienation, and the results were presented in Table 15.

Table 15. Relationship between Students' Hemsehrilik Attitudes and Levels of Alienation

\begin{tabular}{|c|c|c|c|}
\hline & $\mathrm{N}$ & $\mathrm{r}$ & $\mathrm{P}$ \\
\hline $\begin{array}{c}\text { Hemsehrilik \& Student } \\
\text { Alienation }\end{array}$ & 300 & 0.97 & .093 \\
\hline
\end{tabular}

Table 15 indicates that there is not a statistically significant relationship between the levels of alienation and hemsehrilik attitudes of the students $(r=0.97, p>.05)$.

\section{Discussion-Conclusion and Recommendations}

This study investigated levels of alienation and hemsehrilik attitudes of students and also addressed whether sex, grade level, number of siblings and place of residence of family has an effect on levels of alienation and hemsehrilik attitudes.

The results indicate that the students have a moderate level of alienation, which is in parallel with the results of the studies carried out by $[42,43,24,32]$. The fact that each individual differs from every other cognitively, emotionally and socially can lead them to experience a sense of alienation at different levels and intensities. Coming from different countries and provinces, and having more pronounced cultural differences, KTMU students are considered to experience a more intense feeling of alienation. In line with this, Ayhan and Balci [44] state that the Kyrgyz social structure consists of more than 90 nations and the country lacks any ideological and social infrastructure which could integrate this national and cultural diversity together, leaving especially young people vulnerable to social and psychological problems. However, the results suggest that Kyrgyzstan-Turkey Manas University might have given importance to integration activities in accordance with the purpose of establishment. For this reason, the conduct of qualitative studies with the existing sampling group is of importance to better understand the experienced alienation.

Another result of the study suggests that sex is not a significant variable in terms of level of alienation, which is consistent with the results of many studies in the literature $[45,24]$. On the other hand, there are some other studies which indicate that levels of alienation of male students are higher than those of female students $[46,47,43,48,31]$. Şirin [49] accounts for this difference by suggesting that women are more open to communication and have a more humane and sensitive approach to the socialization process than men. Polat et al. [31] consider this difference to be a result of men adapting to educational environment and their surroundings later than women. On the other hand, lack of any statistically significant difference in the levels of alienation between the two sexes in this study suggests that there might be some other factors affecting the alienation experienced by the sample group more. Therefore, regression studies should be conducted on the sources of alienation with similar sample groups in order to determine these factors.

Another result of the study suggests that the levels of alienation of the students are significantly different in terms of grade level. According to this result, the level of alienation of the third grade students is higher than that of the first grade students. This result is similar to those of some studies [46] in the literature whereas it is significantly different from those of some other studies [24]. For example, Ataş and Ayik [46] pointed out that the alienation levels of the fourth grade teacher candidates were higher than those of the first grade students, and Ataş and Ayik [46] accounted for this difference by the fact that the fourth grade teacher candidates were preparing for Public Personnel Selection Examination. From this perspective, the difference in this study may be due to the fact that the contents of the courses in the third grade are more difficult and field-oriented.

Another result of this study is that the place of residence of family leads to a statistically significant difference in the levels of alienation of the students. The result suggests that the levels of alienation of the students whose families live in provinces are higher than those of the students whose families live in districts or villages. This difference may be due to adverse effects of urban life on socialization process. Higher levels of alienation of individuals may be a consequence of modern urban life which leads people to severe their primary bonds and establish relationship patterns based on "benefit" or "interest".

Another result of the study is that the levels of alienation of the students do not differ significantly depending on the number of siblings. On the basis of this result, it can be interpreted that the number of siblings is not a factor affecting the alienation levels of students. However, there are some studies indicating that the number of siblings increases the level of alienation. Polat et al. [31] found that university students with 8 or more siblings had a higher level of alienation. The difference in the result of this study may be accounted for by the fact that the majority of KTMU students come from different countries and cities. Living geographically distant from their families may have hindered their communication not only with their parents but also with their siblings, which may have resulted in the dwindling of 
their social support resources and increased alienation.

Another result is related to the hemsehrilik attitudes of KTMU students. The result shows that the hemsehrilik attitudes of the students are moderate. From a social and political perspective, we can see the presence of two important structures referred to as "clan and tribe" in Kyrgyz society [50]. Not only does the "clan-tribe" system place a "kin-based" relationship to the center of the organization, but it also integrates some other indirect kinship elements such as marriage, family reunification, localism and living in the same neighborhood. For this reason, we can talk about the existence of hemsehrilik type social networks in Kyrgyz culture even though they are not referred to as hemsehrilik. As a matter of fact, the effect of these networks did not lose its power even in Soviet times [50]. It is, therefore, not surprising at all that Kyrgyz students have a moderate hemsehrilik attitude.

Overall, the results reveal that the hemsehrilik attitudes of KTMU students differ significantly depending on sex, place of residence of family and number of siblings while they do not differ depending on grade level. In the analyses related to sex, the male students' scores are higher than those of the female students, which may be due to the differences in the social networks of men and women. According to Moore [51], social network patterns of women are based on kinship relations and exhibit a more limited structure, whereas men often have a wider and diverse structure. Therefore, being born or living in the same neighborhood, village or city may not be sufficient and effective in the process of structuring women's social relations. That being said, studies show that men are more likely to initiate relationships while women are more capable of sustaining them and that men are more actively involved in the establishment of a relationship based on hemsehrilik [52, 53].

The analyses on the place of residence of family reveal that the hemsehrilik attitudes of the students whose families live in provinces are higher than those of the students in the other groups. It is known that migration from the relatively less developed regions to the developed regions of the country especially during the revolutionary periods in Kyrgyzstan resulted in increased urbanization and "shantytownization" especially in Bishkek and its vicinity [54]. It can also be observed in the sample group, $45 \%$ of which consists of students whose families live in provinces. From this perspective, it can be argued that increased urbanization and "shantytownization" may have paved the way for the emergence of different social networks such as hemsehrilik in Kyrgyz society.

Analyses on the number of siblings indicate that the students with fewer than three siblings have higher hemsehrilik attitudes than those with more than three siblings. Having few siblings may have prompted students to establish different relationship mechanisms which would provide them with social support, which, in return, may have led to a significant difference in the hemsehrilik attitudes of the students depending on number of siblings.
This study focuses mainly on the relationship between student alienation and hemsehrilik attitudes. The results of the analyses do not point to a statistically significant relationship between the levels of alienation and hemsehrilik attitudes of KTMU students. These results, contrary to the primary assumption, can be interpreted to mean that hemsehrilik is not a variable which reduces the alienation experienced by Kyrgyz students. Numerous studies investigating the levels of alienation of teacher candidates suggest that the quality of relationships with academics and friends is a factor affecting alienation. In connection with this, it was assumed that the development of a hemsehrilik based understanding and attitude would reduce alienation. However, the fact that the results of the study do not support this assumption calls for the investigation of some other factors playing a role in this phenomenon. It is, therefore, necessary to carry out in-depth research and analyses including sub-dimensions in order to make more precise interpretations.

In conclusion, this study reveals important findings about student alienation and hemsehrilik and shows that the bonds arising from hemsehrilik relations do not have an effect on student alienation. From this perspective, we believe that these findings will be useful to experts in the fields of psychology and sociology to develop new insight into psychological and social realities of university students in particular and will contribute to a better understanding of the social structure of Kyrgyzstan in general.

\section{REFERENCES}

[1] Çağlar, Ç. (2012). Öğrenci Yabancilaşma Ölçeği'nin (ÖYÖ) Geliştirilmesi. Eğitim ve Bilim, 37, 166, 195-205.

[2] Öksüz, Y. (2012). Developing An Attitude Scale Of University Student Towards "Hemş̧ehrilik": Study of Reliability and Validity [Üniversite Öğrencileri Hemșehrilik Tutum Ölçeği]. Energy Education Science and Technology: Social and Educational Studies, 4(3), 1395-1404.

[3] Avci, M. (2012). Eğitimde Temel Bir Sorun: Yabancilaşma. Atatürk Üniversitesi Sosyal Bilimler Enstitüsü Dergisi, 16 (3), $23-40$.

[4] Horney, K. (1950). Neurosis and human growth. New York: W. W. Norton and Company.

[5] Finifter, A. W. (1972). Alienation and the social system. New York: John Wiley and Sons, Inc.

[6] Tolan, B. (1981). Çağdaş Toplumun Bunalimi: Anomi ve Yabancilaşma. Ankara: İTİA Yayinlari.

[7] Sidorkin, A. M. (2004). In the event of learning: alienation and participative thinking in education. Educational Theory, 54(3), 251-262.

[8] Şimşek, H., Katitaş, S. (2014). İlköğretim İkinci Kademe Öğrencilerinde Okula Yabancilaşmanin Çeşitli Değişkenler Açisindan İncelenmesi (Şanliurfa İli Örneği). Ahi Evran Üniversitesi Kirşehir Eğitim Fakültesi Dergisi, 15(1), 85-99. 
[9] Bayindir, B. (2002). Ortaöğretim dal öğretmenlerinin mesleğe yabancilaşmalari ile öğretme-öğrenme sürecindeki davranişlari arasindaki ilişki, (Yayimlanmamiş Yüksek Lisans Tezi) Anadolu Üniversitesi Eğitim Bilimleri Enstitüsü, Eskişehir.

[10] Çevik, R. (2009). Ortaöğretim kurumlarinda yönetici davranişlarinin öğretmenlerin mesleklerine yabancilaşmasina etkisi. Yayinlanmamiş Yüksek Lisans Tezi, Yeditepe Üniversitesi Sosyal Bilimleri Enstitüsü, İstanbul.

[11] Erjem, Y. (2005). Eğitimde yabancilaşma olgusu ve öğretmen: Lise ögretmenleri üzerine sosyolojik bir araştirma (Elektronik sürüm). Türk Eğitim Bilimleri Dergisi. 4 (3), 2008, from http://www.tebd.gazi.edu.tr/c3s4.html.

[12] Şimşek, H., Balay, R., Şimşek, A.S. (2012). İlköğretim Sinif Öğretmenlerinde Mesleki Yabancilaşma. Eğitim Bilimleri Araştirmalari Dergisi, 2(1), 53-72.

[13] Şimşek, H., Abuzar, C., Yegin, İ.H., Şimşek, S., \& Demir, A. (2014). Okula Yabancilaşma Ölçeği. Ahi Evran Üniversitesi Kirşehir Eğitim Fakültesi Dergisi, 16(4), 309-322.

[14] Es, Lee. (2004). The Influencing Factors on Alienation in High School Students. Journal of Korean Academy of Nursing, $34(1), 45-52$.

[15] Yiğit, S. (2010). İlköğretim 5, 6., 7. ve 8. sinif öğrencilerinin okula yabancilaşma düzeylerinin çeşitli değişkenler açisindan incelenmesi. Yayinlanmamiş yüksek lisans tezi, Zonguldak Karaelmas Üniversitesi Sosyal Bilimler Enstitüsü, Zonguldak.

[16] Hosgörür, V. (1997). Eğitim iş görenlerinin örgütsel tutumlari(Samsun İli Ortaöğretim Okullari Örneği). Yayinlanmamiş Doktora Tezi. Ankara Üniversitesi Sosyal Bilimler Enstitüsü, Samsun.

[17] Mau, R.Y. (1992). The validity and devolution of a concept: student alienation. Adolescence, 27 (107), ERIC: EJ451214.

[18] Yilmaz, S., Sarpkaya, P. (2009). Eğitim Örgütlerinde Yabancilașma ve Yönetimi. Uluslararasi İnsan Bilimleri Dergisi, 6(2), 314-333.

[19] Aydin, S., \& Akar, H. (2015). Öğretmen Adaylarinin Yabancilaşma Düzeylerine Fakülte Yaşam Niteliğinin Etkisinin İncelenmesi. Eğitim ve Öğretim Araştirmalari Dergisi, 4(2), 161-172

[20] Atli,A., Keldal, G., Sonar, O. (2015). Üniversite Öğrencilerinin Yabancilaşma ile Yalnizlik Düzeyleri Arasindaki İlişki. Mustafa Kemal Üniversitesi Dergisi, 12, 29, 149-160.

[21] Ayik, A., Uzun, T., Atas, Ö. ve Yücel, E. (2015). Öğrencilerin Sinizm Tutumlari ve Okula Yabancilaşma Algilari Arasindaki İlişkilerin İncelenmesi, The Journal Of Academic Social Science Studies, 39, p. 491-508.

[22] Çiftçi, G. (2009). İlköğretim okullarinin bürokratikleşme düzeyi ile öğrenci yabancilaşmasi arasindaki ilişki. Yayinlanmamiş yüksek lisans tezi, Pamukkale Üniversitesi Sosyal Bilimler Enstitüsü, Denizli.

[23] Çivitçi, N. (2011). Lise öğrencilerinde okul öfkesinin yordayicilari olarak okula yabancilaşma ve algilanan sosyal destek. Elementary Education Online, 10(3), 861-871, 2011.

[24] Çelik, E., Babaoğlan, E. (2016). Bozok Üniversitesi Öğrencilerinin Yabancilaşma Düzeyi. Uluslararasi Bozok Sempozyumu, 5-7 Mayis 2016.
[25] Erimez, C., Gizir, S. (2013). Eğitim Fakültesi Öğrencilerinin Öğretmenlik Mesleğine Yönelik tutumlarinda Fakültelerine Yabancilaşmalarinin Rolü, MEÜ Eğitim Fakültesi Dergisi, 9(3), 13-26.

[26] Kaçire, İ. (2016). The Impact of the University Students' Level of Alienation on Their Perception of General Satisfaction. International Journal of Higher Education, 5(1), 38-46.

[27] Kir, İ., Altay, C.A., Ceyhan, E. (2014). Lise 9.Sinif Öğrencilerinin Yabancilaşma Düzeylerinin ve Şiddete Yönelik Tutumlarinin Bazi Değișkenler Açisindan İncelenmesi. Kahramanmaraş Sütçü İmam Üniversitesi Sosyal Bilimler Dergisi, 11(1), 155-174.

[28] Kocayörük, E. (2007). Lise Öğrencilerinin Yabancilaşmalari ile Anne Baba İlişkileri Arasindaki İlişkinin İncelenmesi. Eğitim Bilim Toplum,5(17), 92-111.

[29] Kocayörük, E., Şimşek, Ö. F. (2014). Parental Attachment and Adolescents' Perception of School Alienation. The Mediation Role of Self-Esteem and Adjustment. The Journal of Psychology, 150:4, 405-421, DOI:10.1080/00223980.2015.1060185.

[30] Özaydinlik, K., Kabaran, H., Altintaş, S., Göçen Kabaran, G. (2016). Eğitim Fakültesi Öğrencilerinin Yabancilaşma Düzeyleri İle Öğretmenlik Mesleğine Yönelik Duyarlilik Düzeyleri Ve Yeterlik Algilari Arasindaki İlişkinin İncelenmesi (Muğla Sitki Koçman Üniversitesi Örneği). Kastamonu Eğitim Dergisi, 24:4, 1673-1690.

[31] Polat, M., Dilekmen, M., Yasul, A.F. (2015). Öğretmen Adaylarinda Okula Yabancilaşma ve Akademik Öz-Yeterlik: Bir Chaid Analizi İncelemesi. Uluslararasi Eğitim Bilimleri Dergisi, 2, 4, 214-232.

[32] Şimşek H., Ataş Akdemir, Ö. (2015). Üniversite Öğrencilerinde Okula Yabancilaşma. Current Research Education, 1(1), 1-12.

[33] Türk, F. (2010). Alienation in Education. International Journal of Educational Policies, 8(1), 41-58.

[34] Uzun-Yüksek, Ö. (2006). İlköğretim 5. sinif öğrencilerinin okula yabancilaşma düzeylerine etki eden sosyo-demografik değişkenlerin belirlenmesi. Yayimlanmamiş yüksek lisans tezi. Çukurova Üniversitesi Sosyal Bilimler Enstitüsü, Adana.

[35] Yanik, M., Çamliyer, H. (2015). Ortaöğretim 9.Sinif Öğrencilerinin Beden Eğitimi ve Spora İlişkin Tutumlari ile Okula Yabancilaşma Düzeyleri Arasindaki İlişkinin Belirlenmesi. Uluslararasi Spor, Egzersiz ve Antrenman Bilimi Dergisi, 1(1), 9-19, DOI: 10.18826/ijsets.95709.

[36] Yilmaz, Ö. Antepli, S. (2011). Yaratici Dramanin Okula Yabancilaşma Yaşayan İlköğretim 5.Sinif Öğrencileri Üzerindeki Etkisinin Çocuklarin Tiyatrosu Yoluyla İncelenmesi. Yaratici Drama Dergisi, 6, 11, 75-92.

[37] Johnson, G. M. (2005). Student alienation, academic achievement, and webCT use. Educational Technology \& Society, 8, 179-189.

[38] Gizir, S. (2005). Assessment of factor s negatively affecting communication process in Turkish State Universities. Yayinlanmamiş doktora tezi, Orta Doğu Teknik Üniversitesi, Ankara

[39] Hurtado, S., Milem, J.F., Clayton-Pedersen, A.R., and Allen, W.R. (1999). Enacting diverse learning environments: Improving the campus climate for racial/ethnic diversity. ASHE/ERIC Higher Education Reports Series. 
[40] KTMÜ Öğrenci İşleri Verileri (2017), manas.edu.kg.

[41] Karasar, N. (2006). Bilimsel Araştirma Yöntemleri. Ankara: Nobel Yayincilik

[42] Coşkun, Y., Altay, C.A. (2009). Lise Öğrencilerinde Yabancilaşma ve Benlik Algisi İlişkisi. M.Ü. Atatürk Eğitim Fakültesi Eğitim Bilimleri Dergisi, 29, 41-56.

[43] Çağlar, Ç. (2013). Eğitim Fakültesi Öğrencilerinin Yabancilaşma Düzeyleri ile Öğretmenlik Mesleğine Yönelik Tutumlari Arasindaki İlişki. Kuram ve Uygulamada Eğitim Bilimleri, 13(3), 1497-1513

[44] Ayhan, B., Balci, Ş. (2009). Kirgizistan'da Üniversite Gençliği ve İnternet: Bir Kullanimlar ve Doyumlar Araştirmasi. Bilig, 48, 13-40.

[45] Apriyanti, H.K. (2016). Alienation among University of Indonesia's Psychology Students: A Comparative Study amongst First-Year, Second-Year and Third-Year Students. Makara Hubs-Asia, 20(1), 37-45.

[46] Ataş, Ö. ve Ayik, A. (2013). Öğretmen Adaylarinda Okula Yabancilaşma. International Periodical For The Languages, Literature and History of Turkish or Turkic, 8(8), 103-122.

[47] Brown, M.R., Higgins, K., Pierce, T., Hong, E., \& Thoma, C. (2003). Secondary Students' Perceptions of School Life With Regard to Alienation: The Effects of Disability, Gender and Race. Learnind Diasbility Quarterly, 26, 227-238.
[48] Erbaş, M.K. (2014). The Relationship Between Alienation Levels of Physical Education Teacher Candidates and Their Attitudes towards the Teaching Profession. Aiustralian Journal of Teacher Education, 39, 8, 37-52.

[49] Şirin, E. F. (2009). The search of the physical education teachers work alienation level according to some variables. Celal Bayar Üniversitesi Beden Eğitimi ve Spor Bilimleri Dergisi, 4(4), 164-177.

[50] Öraz, S. (2012). Kirgiz Siyasi Hayatinda Aşiretçilik ve Klan Siyaseti. Türk Dünyasi İncelemeleri Dergisi, 12(1), 211-238.

[51] Moore, G. (1990). Structural determinants of men's and women's personal networks. American Sociological Review, $55,726-735$

[52] Erder, S. (2002). Urban Migration and Reconstruction of Kinship Networks: The Case of Istanbul. Rita Liljestrom and Elisabeth Ozdalga (der.) Autonomy and Dependence in the Family: Turkey And Sweden in Critical Perspective içinde (117-136), Istanbul: Swedish Research Institute.

[53] Özbay, F. (2014). Akrabalik ve Komşuluk İlişkileri. Türkiye Aile Yapisi Araştirmasi Analiz Raporu, Ankara.

[54] Gündoğdu, A. (2011). Kirgizistan: Dün, Bugün, Yarin. Hacettepe Üniversitesi Türkiyat Araştirmalari Dergisi, 15, 399-417. 